TITLE:

A New Species of the Genus
Paralaophontodes (Crustacea,
Copepoda, Harpacticoida) from
Interstitial Waters of Mindoro Island
(The Philippines)

$\operatorname{AUTHOR}(S)$ :

Baldari, Fabiola; Cottarelli, Vezio

CITATION:

Baldari, Fabiola ... [et al]. A New Species of the Genus Paralaophontodes (Crustacea,

Copepoda, Harpacticoida) from Interstitial Waters of Mindoro Island (The Philippines).

PUBLICATIONS OF THE SETO MARINE BIOLOGICAL LABORATORY 1986, 31(3-6): 163-168

ISSUE DATE:

1986-11-29

URL:

http://hdl.handle.net/2433/176128

RIGHT: 


\title{
A New Species of the Genus Paralaophontodes (Crustacea, Copepoda, Harpacticoida) from Interstitial Waters of Mindoro Island (The Philippines)
}

\author{
By
}

\section{Fabiola Baldari and Vezio Cottarelli}

Department of Animal and Human Biology, "La Sapienza" University, 00100 Rome, Italy

With Text-figures $1-3$

\begin{abstract}
A new species of interstitial Ancorabolidae, Paralaophontodes elegans $\mathrm{n}$. sp. from the Philippine Islands (Mindoro Island) is described. The new species is particularly characterized by the dorsal ornamentation of cephalothorax and the presence of residual endopodite on female P3. Some morphological characters concerning the new and known species suggested some remarks on the diagnosis of the genus Paralaophontodes.
\end{abstract}

A new species of the genus Paralaophontodes Lang (Ancorabolidae Sars, Lang: Laophontidinae Lang) collected in interstitial waters of Mindoro Island, is described and discussed in this paper. Some remarks on the systematics and biogeography of the poorly known genus Paralaophontodes are also given.

Research carried out with the support of the 'Consiglio Nazionale delle Ricerche' contract $\mathrm{n}^{\circ}$ 0989420, 'Gruppo di Biologia naturalistica'.

\section{Paralaophontodes elegans n. sp.}

(Figs 1-3)

Material: 19 collected on 17.IV.1984 (Vezio Cottarelli leg.) according to the method suggested by Karaman-Chappuis on the "La Laguna" beach, near Sabang-Village (The Philippines, Mindoro Island, Oriental Province). Holotype: The same female prepared in polyvinyl-lactophenole, on a slide marked as P. elegans ht. The specimen is part of the Author's collection, in the Zoological Museum of the Department of Animal and Human Biology, "La Sapienza" University, Rome.

Description. Habitus (Fig. 1-A): length, from the apex of rostrum to the distal margin of the anal operculum, $0.53 \mathrm{~mm}$. Cephalothorax laterally running out into two triangular processes, the anterior one without seta but the posterior with a thin-little seta. Dorsal surface with a complicated system of ridges, a set of setae in the middle part, and posteriorly running out into two couples of recurved processes furnished with a little seta. Thoracic somites laterally more or less triangularly produced with a small seta. Each somite posteriorly with two recurved dorsal processes, each process with a small seta. Somites $2-4$ also having in the

Publ. Seto Mar. Biol. Lab., 31 (3/6), 163-168, $1986 . \quad$ (Article 7) 


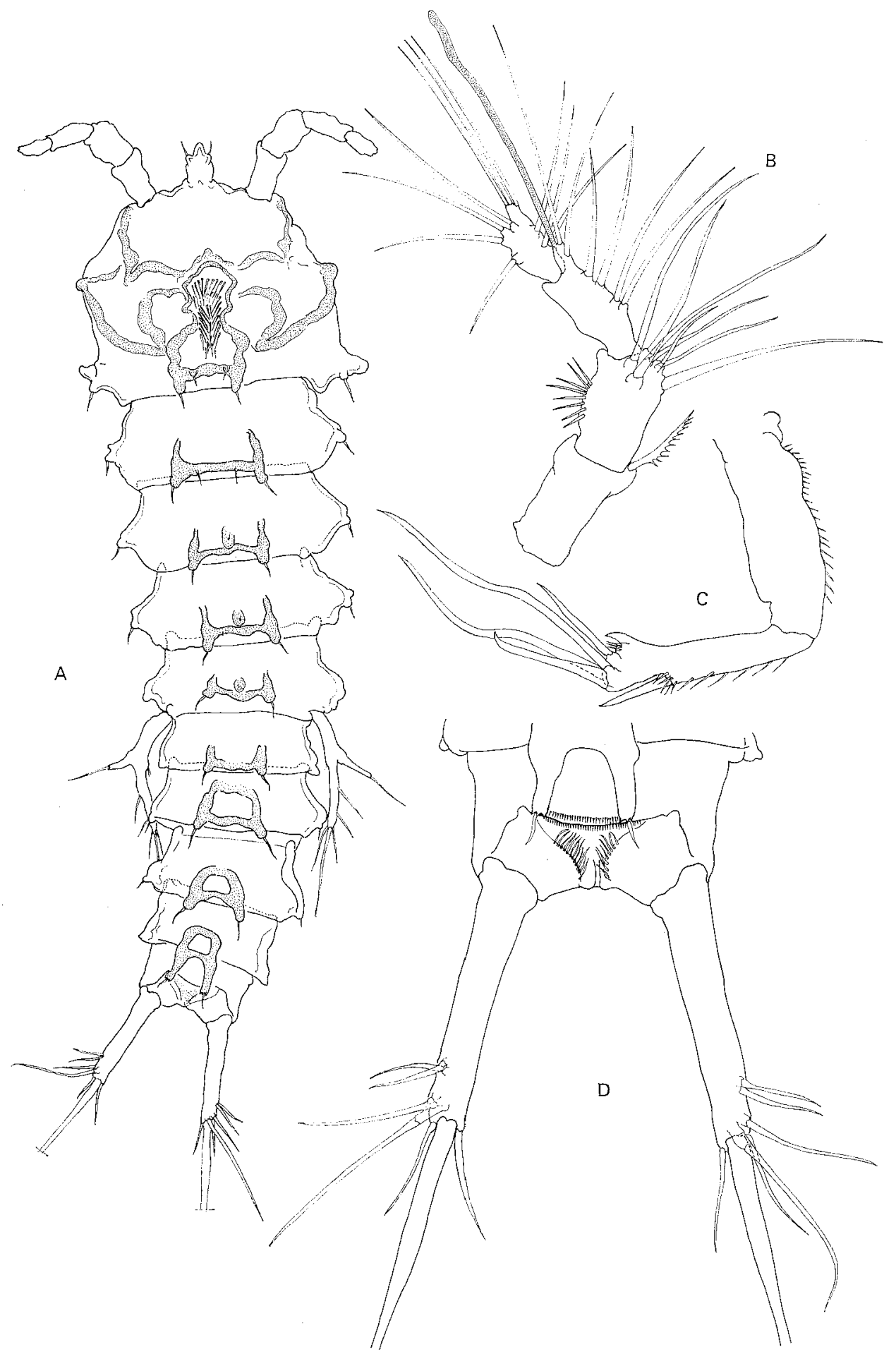

Fig. 1. Paralaophontodes elegans n. sp. Holotypus 9. A. Habitus; B. Antennula; C. Antenna; D. Furcal rami and anal operculum. A: $\times 500 ;$ B-D: $\times 1250$. 
middle a little distinguishable process. Only the first somite has near the recurved processes two tubercles, each having a short and thin seta. Abdominal somites with two recurved dorsal processes, each having one seta. Ventral view of abdominal somites as shown in Fig. 3-A. Rostrum (Fig. 1-A) prominent, with a short and thin seta on each side of the curved tip. Anal operculum (Fig. 1-D): Distal margin with a double row of thin setae. Furcal rami (Fig. 1-D) cylindrical and slender. Outer margin with two setae and two other closely articulated setae all near the distal part, that has one strong and long terminal seta on each side flanked by a shorter seta. Genital area as shown in Fig. 2-B.

Antennula (Fig. 1-B) four-segmented. First two segments of about equal length, the first with a strong plumose seta on the inner distal corner, the second with short and thin setae on the outer margin and some long setae on the opposite margin, arranged as in figure. Third segment with a lateral distal apophysis with two long setae and one slender aesthetasc. Last segment having long setae on both margins, and three apical setae. Antenna (Fig. 1-G): Coxa very short. Allobasis and endopodite of about equal length. Exopodite lacking. Ornamentation as in figure.

Maxilliped as shown in Fig. 3-G. Mandible (Fig. 3-D): Pars incisiva armed as shown in figure. Mandibular palp with two apical haired-setae and three lateral setae. Maxillula (Fig. 3-B): Arthrite of praecoxa distally with four curved spines and two apical setae. Coxa with a long apical seta. Basis with two apical setae and three setae on outer margin. Maxilla (Fig. 3-E): Endopodite represented by a very short article with one seta. Syncoxa with two endites bearing three and two setae respectively.

Pl (Fig. 2-D): Exopodite of two articles, the first short-haired both along outer and distal margins, with one strong seta on the outer corner, the last much longer, with four setae distally. Endopodite of two articles, the distal one with a strong and long claw. P2-P4 (Fig. 2-F, E, C): Coxa much shorter and broader than basis, with a row of spiniform setae on the inner margin. Basis with a long outer seta and some short spinules on the distal part. Endopodite P3 very reduced, represented by a tubercle with an apical seta. P2 and P4 without endopodite. Exopodite P2-P4 with three segments, first two armed with one outer spine; last segment markedly increasing in length from $\mathrm{P} 2$ to $\mathrm{P} 4$, with one apical and three outer spines and a thin seta on inner distal corner; all segments fringed with spinules. P5 (Fig. 2-A): Basiendopodite with an outer digitiform process which is nearly half as long as exopodite segment and armed apially with one long haired seta. Exopodite well developed, elongated with one apical haired seta and others two subapical. Two plumose setae also on its inner margin, and on the opposite side two closely set, small setae proximally.

Remarks. It might be criticizable the description of $P$. elegans founded here on only one specimen, but both the combination of the described characters, which can identify the species, and the geographic occurrence get us to regard this Paralaophontodes as a new species. 


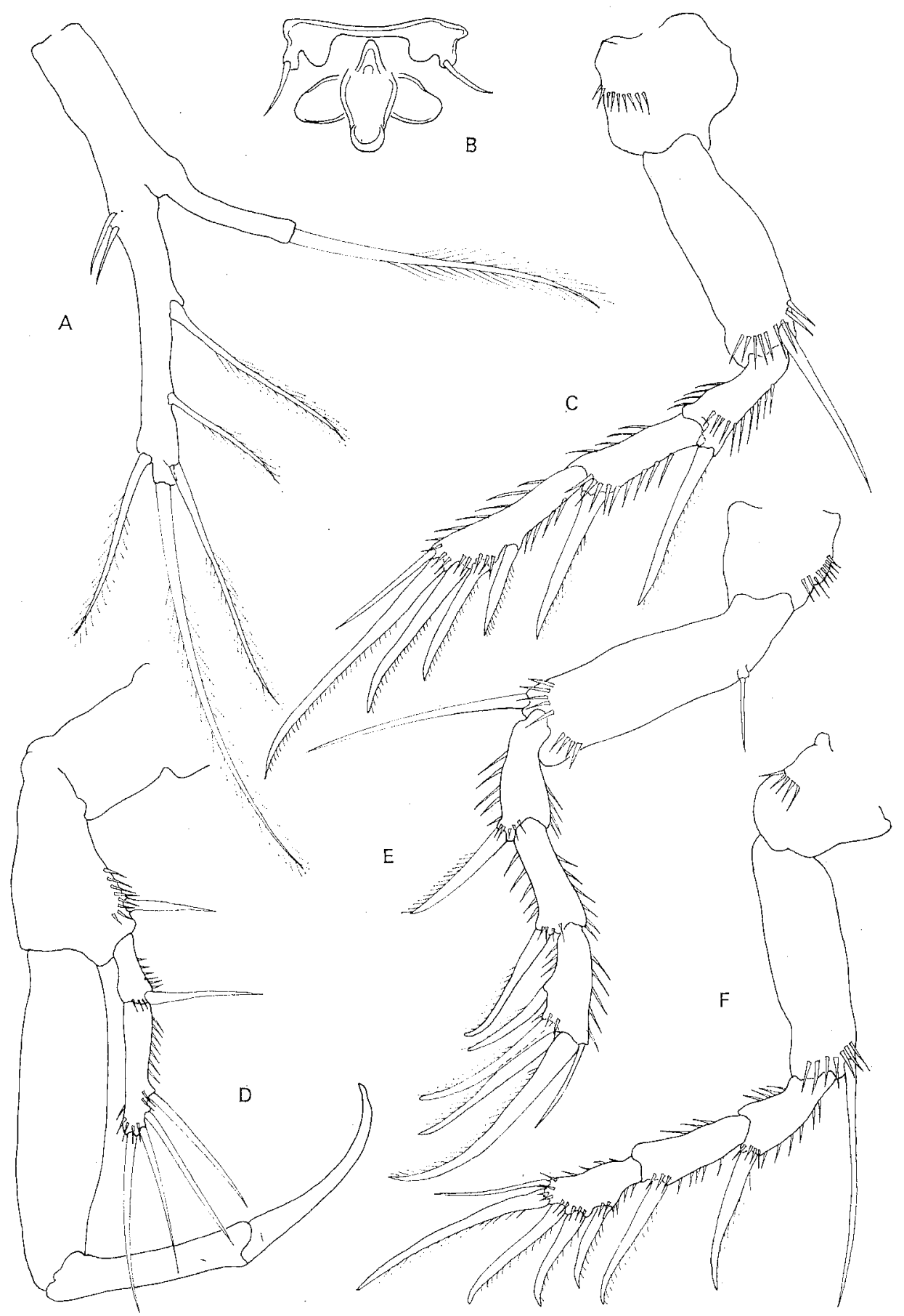

Fig. 2. Paralaophontodes elegans n. sp. Holotypus ㅇ. A. P5; B. Genital area; C. P4; D. P1; E. P3; F. P2. A-F: $\times 1250$. 


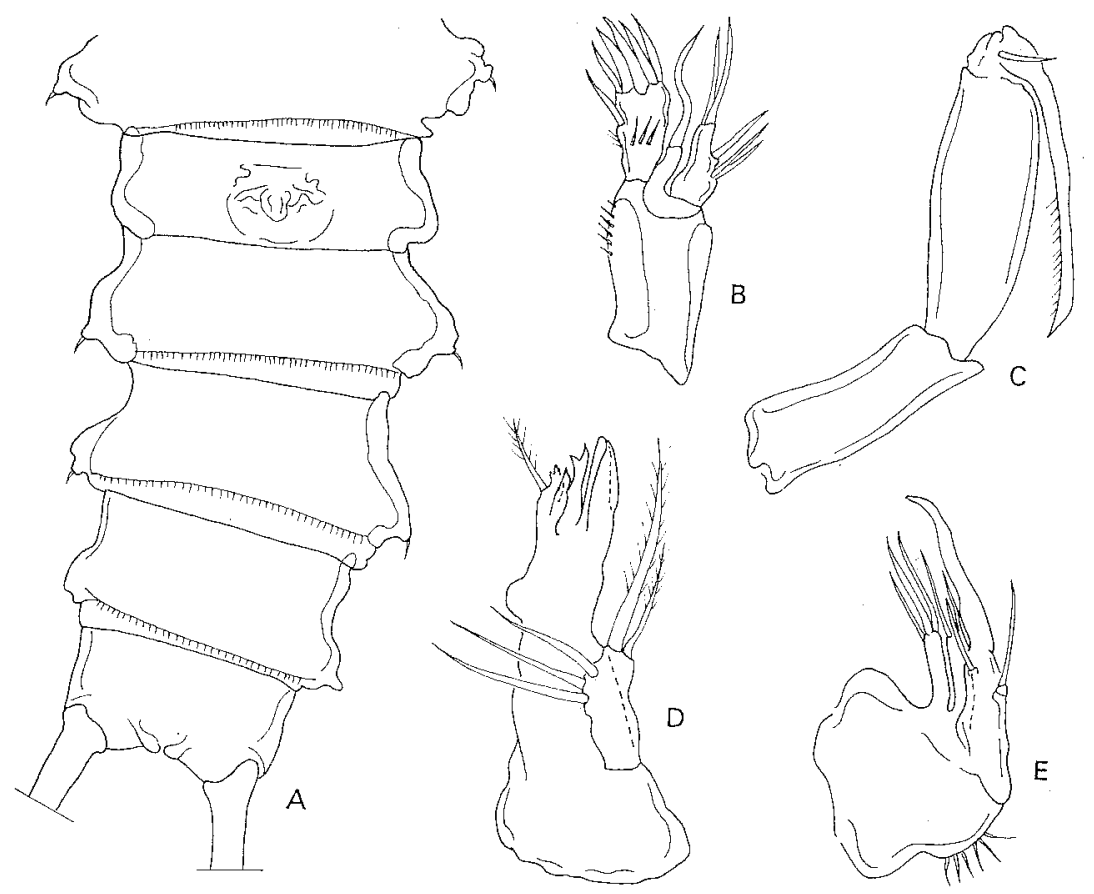

Fig. 3. Paralaophontodes elegans n. sp. Holotypus ㅇ. A. Abdominal somites, ventral view; B. Maxillula; C. Maxilliped; D. Mandible; E. Maxilla. A: $\times 500 ;$ B-E: $\times 1250$.

We point out that $P$. elegans $n$. sp. is the only known species of the genus having a dorsal ornamentation of cephalothorax, as described and discussed by Lang (1965) for Laophontodes hedgpethi. Furthermore the new species is peculiar for the chaetotaxy of P5 being without the strong inner seta. Comparing the iconographies of different species (except for the approximatively-drawn $P$. echinatus) P. elegans n. sp. has the furcal rami proportionally shorter (length/width 6.8).

To single out the relationship is difficult because this could change depending on the different choice characters. On the one hand the residual endopodite P3 makes $P$. elegans n. sp. similar to $P$. exopoditus and perhaps $P$. echinatus)(see Willey, 1930). On the other hand both the absence of exopodite on the antenna and the number of the distal setae on the PI becomes $P$. elegans n. sp. similar to all species excluding $P$. exopoditus.

At present the genus Paralaophontodes Lang, 1965 includes four species: P. echinatus (Willey, 1930) from Bermuda; P. robustus (Bozic, 1964) from Reunion I. and Mediterranean Sea (Bodin, 1964, 1968; Dinet, 1971); P. exopoditus Mielke, 1981, from Galapagos; P. elegans n. sp. from the Philippines.

Both the description of $P$. exopoditus and the discovery of $P$. elegans $\mathrm{n}$. sp. entail some changes as regards that pointed out by Lang in 1965 about the genus. Consequently, considering the characters discussed for affinity, we suggest the following diagnosis of the genus Paralaophontodes: Ancorabolidae with exopodite of antenna residual or absent; exopodite P1 of two segments, the distal one having four or five 
setae; female and male endopodite $\mathrm{P} 2$ and $\mathrm{P} 4$ absent; female endopodite P3 residual or absent.

Etymology. The latine adjective "elegans" refers to the smart habitus of this species.

Diagnosis. A Paralaophontodes distinguishable by the following combination of characters: dorsal surface of cephalothorax with a set of setae; antenna without exodite; exopodite P1 with four distal setac; P3 with residual endopodite; P5 with reduced chaetotaxy; relatively short furcal rami.

\section{References}

Bodin, P. 1964. Recherches sur la systématique et la distribution des Copépodes Harpacticoides des substrats meubles des environs de Marseille. Rec. Trav. St. Mar. End., 33: 107-183.

- 1968. Recherches sur la systématique et la distribution des Copépodes Harpacticoides des substrats meubles des environs de Marseille. Note complémentaire. Rec. Trav. St. Mar. End., 43: 271-277.

Bozic, B. 1964. Copépodes Harpacticoides et Gyclopoides de la Reunion. II. Plage St. Pierre. Bull. Mus. Nat. Hist. Nat., 36: 481-499.

Dinet, A. 1971. Copépodes Harpacticoides d'un sable fin organogéne des environs de Marseille. Tethys, 2 (3): 747-762.

Lang, K. 1965. Copepoda Harpacticoidea from the Californian Pacific coast. Kungl. Svenska Vetenskaps. Handl., 10: 1-566.

Mielke, W. 1981. Interstitielle Fauna von Galapagos. XXVIII. Laophontinae (Laophontidae), Ancorabolidae (Harpacticoida). Mikrof. Meeresb., 84: 119-222.

Willey, A. 1930. Harpacticoida Copepoda from Bermuda. Part I. Ann. Mag. Nat. Hist., 10 (6): 81-114. 